\title{
To rout or snort in the sleepe: a detailed medical description of sleep disordered breathing and its consequences by Georg Grau in 1688
}

To the Editor:

To date, the description of the excessive sleepiness of "Joe the fat boy" depicted in The Pickwick Papers by Charles Dickens is widely considered to be the first poetical portrayal of sleep disordered breathing (SDB) $[1,2]$. The clinical significance of SDB, however, was not recognised until the second half of the 20th century $[2,3]$. In Hypnologia, a compendium on sleep written by Georg Grau in 1688, which has recently been rediscovered, the author presents an astonishingly accurate description of a series of symptoms that today can be regarded as portraying a complete picture of SDB and/or the obstructive sleep apnoea syndrome [4]. This compendium will be introduced briefly below.

The Hypnologia was published in 1688 in Jena, Germany (figure 1). The book is structured as 30 questions discussing several aspects of normal and disturbed sleep [4]. Herein we present excerpts from questions XIV, XV and XVI, dealing with SDB. The entire text of the questions including the Modern English translation is provided as an appendix.

Starting with the social consequences of snoring (Snoring is an irritating, arduous and unpleasant night music for those who sleep close by, question XVI) Grau continues with a detailed description of the sequence of upper airway pathology during sleep. An increase in upper airway (nasal) resistance (It is nothing more or less than the air trapped in the nose, because it cannot pass through the nose freely and unhindered, question XVI) is followed by a narrowing of the pharyngeal lumen and complete pharyngeal airway collapse. The latter results in paradoxical thoracoabdominal excursion (Mueller manoeuvre) (Snoring and wheezing follows from the fact that, in a supine position, the back and the chest are really close to each other, reducing the space for breathing, so that the chest must heave with quite an effort, question $\mathrm{XIV}$ ) and culminates in breathing arrest (sleep apnoea) (For, the external air cannot get into the lungs so freely... so that it can get into and out of the lungs only very slowly, question XV) [4].

He identified a supine sleep position (Sleeping in a supine position is harmful, question XV; ...those who are used to keeping a supine position when sleeping, question XVI), overweight, and alcohol intake before bedtime as relevant risk factors for SDB (Mostly, it is strong eaters and drinkers who sleep with their mouths open, question XV; ...go to sleep intoxicated, question XVI) [4].

Finally, Grau gives a detailed summary of SDB-related health implications. Grau recognised the association between SDB and polyglobulia (Those who by nature have thick blood, question XVI), and identified nightmares, gout, seizures and stroke as medical consequences of SDB (All kinds of illnesses and discomforts, such as nightmares, serious plight, gout, cramp, stroke and others. For, the brain is thus unable to clean out or export its impurities through the eyes/nose and mouth, question XIV) [4].

In the database of the German National Library, there are more than 15 variants of the physician Georg Grau's name. In Hypnologia, the author is given the names Georg Graven (title) and Georg Grav (page 12). Grau came from Coburg in North Bavaria. He matriculated at Jena University in Thuringia in 1650 (handwritten inscription in the Jena University matriculation registry: Grave/Graff, Georg, Coburg Franc.,

@ERSpublications

Description of sleep disordered breathing and its consequences was made as early as the 17th century, including upper airway pathology during sleep, risk factors for SDB and medical consequences, simply based on detailed medical observation and examination http://ow.ly/SVRq30o98KV

Cite this article as: Rupprecht S, Schönefeld D, Kroegel N, et al. To rout or snort in the sleepe: a detailed medical description of sleep disordered breathing and its consequences by Georg Grau in 1688. Eur Respir J 2019; 53: 1801799 [https://doi.org/10.1183/13993003.01799-2018]. 


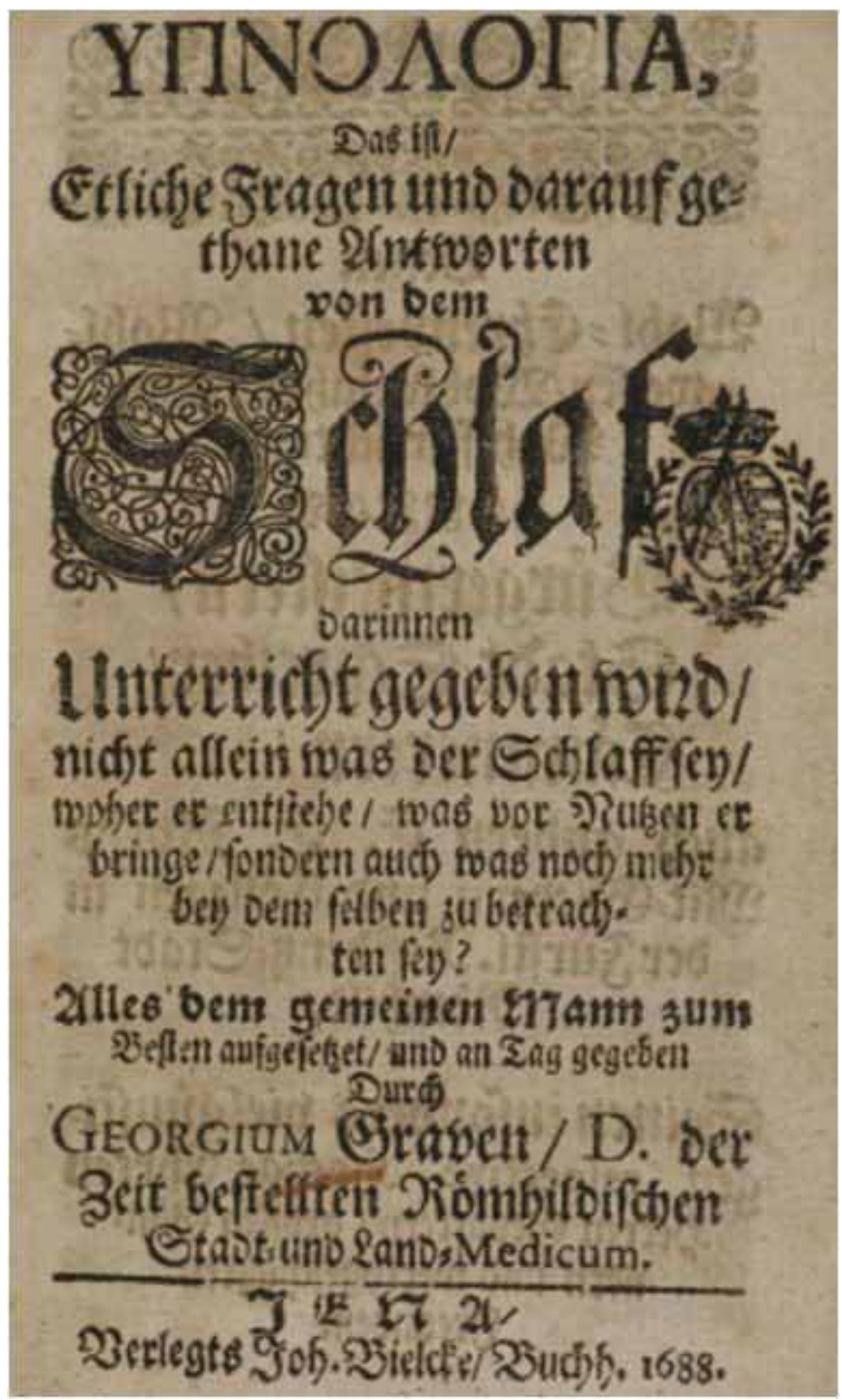

FIGURE 1 Front page of Hypnologia, published by Georg Grau in 1688. The page reads as follows. Hypnologia, Das ist Etliche Fragen und darauf gethane Antworten von dem Schlaf darinnen Unterricht gegeben wird / nicht allein was der Schlaf sey / woher er entstehe / was vor Nutzen er bringe / sondern auch was noch mehr bey demselben zu betrachten sey? Alles was dem gemeinen Mann zum Besten aufgesetzet / und an den Tag gegeben Durch GEORGIUM Graven / D. der Zeit bestellten Römhildischen Stadt-und Land-Medicum. [Hypnologia - is concerned with quite a few questions about sleep and the answers given to them as they turn up in the course of instruction. It does not only ask what sleep is, how it comes about and what is the good of it, but it also inquires into what else needs to be considered about it. All this was compiled to the best of the common man and made known by Georg Grau, currently employed as medical doctor of the town of Römhild and its rural environment.]

imm. 5.6. 1650, page 325) and received his medical doctorate in 1660 (inscription in the Jena University registry: Gravius, Georg, Coburg, Dr. med. 7. 2. 1660, page 392). Subsequently, he worked as a physician in Römhild and Behrungen, Thuringia. In addition to Hypnologia, he wrote several books, including one entitled Short lessons for midwives. His work seemed to be influenced by Levinus Lemnius (1505-1568), a Dutch physician and scholar of Andreas Vesal. The Hypnologia contains several text passages directly referring to Lemnius (At another place, the deep thinking scholar Lemnius adds that by sleeping with one's mouth shut, the natural warmth of the body can be retained much better, which contributes to an even better digestion, question $\mathrm{XV})[4,5]$.

Grau's medical and theoretical conceptions were naturally rooted in the Theory of the Four Humours, but his remarks on SDB are captivated by an exact medical observation of upper airway pathology during sleep, including its risk factors and medical consequences. Although at that time he did not realise the association between daytime sleepiness and SDB, he characterised SDB and its potential medical consequences as early as in the 17th century and, consequently, he should be honoured as a pioneer in sleep and respiratory medicine. 
Sven Rupprecht ${ }^{1,2,3,6}$, Doris Schönefeld ${ }^{4,6}$, Nasim Kroegel ${ }^{2}$, Otto W. Witte ${ }^{2}$, Matthias Schwab ${ }^{1,2}$ and Ekkehart Paditz ${ }^{5}$

${ }^{1}$ Interdisciplinary Centre for Sleep and Respiratory Medicine, Jena University Hospital, Jena, Germany. ${ }^{2}$ Hans Berger Dept of Neurology, Jena University Hospital, Jena, Germany. ${ }^{3}$ Research Programme "Else Kröner-Forschungskolleg AntiAge", Jena University Hospital, Jena, Germany. ${ }^{4}$ Institute of British Studies, University of Leipzig, Leipzig, Germany. ${ }^{5}$ Centre for Applied Disease Prevention, Dresden, Germany. ${ }^{6}$ Both authors contributed equally to this work.

Correspondence: Sven Rupprecht, Hans Berger Dept of Neurology, Jena University Hospital, Am Klinikum 1, D-07747 Jena, Germany. E-mail: sven.rupprecht@med.uni-jena.de

Received: Sept 212018 | Accepted after revision: Feb 032019

Author contributions: S. Rupprecht and N. Kroegel drafted the manuscript. E. Paditz and S. Rupprecht performed the historical research in the archives and libraries. D. Schönefeld translated the given excerpts from Early Modern German to Modern English. O.W. Witte and M. Schwab gave intellectual input and revised the manuscript.

Conflict of interest: S. Rupprecht has nothing to disclose. D. Schönefeld has nothing to disclose. N. Kroegel has nothing to disclose. O.W. Witte has nothing to disclose. M. Schwab has nothing to disclose. E. Paditz is managing director and owner of the publishing house Kleanthes for medicine and prevention in Dresden, Germany, which in 2013 reproduced the historical book by Georg Grau with cooperation and authorisation from the University and State Library of Saxony, republishing the book in a very limited edition.

\section{Appendix 1.}

German original citation and corresponding English translation of questions XIV, XV and XVI of the Hypnologia, published by Georg Grau in 1688 .

\section{Die XIV. Frage. Auf welcher Seiten soll man zu erst und am meisten schlafen?}

Schnarchen und Schnauffen machet / denn der Rückgrad einwarts / und die Brust obwarts zusammendringen / auch dem Athem seinen Raum benehmen / daß die Brust in athemen gar sehr über sich heben muß / dahero denn allerhand Zufäll aus solchem Liegen entstehen / als der Alp oder Nachtdrücken / schwere Noth / Gicht / Krampff / Schlag / und andere mehr / denn das Hirn kann sich also von seiner Unreinigkeit durch die Augen / Nasen und Mund nicht saubern / noch derselben ausführen.

\section{Question XIV. Which side is it that one shall sleep on first and foremost?}

Snoring and wheezing follows from the fact that, in a supine position, the back and the chest are really close to each other, reducing the space for breathing, so that the chest must heave with quite an effort. Therefore, sleeping in such a position may provoke all kinds of illnesses and discomforts, such as nightmares, serious plight, gout, cramp, stroke and others. For, the brain is thus unable to clean out or export its impurities through the eyes/nose and mouth.

\section{Die XV. Frage. Ob das Schlafen mit offenem Munde Schaden bringe?}

Das Schlafen mit offenem Munde ist meistens der Fresser und Säufer Art / wiewol auch etliche sind / die aus Noth mit offenem Munde schlafen müssen / weil ihre Nasenlöcher zu enge sind / daß sie durch dieselbe nicht sattsam athemen können: andere thun solches aus Faulheit / weil sie die Nasenlöcher von dem Koth / so darinnen stecket / nicht säubern mögen / daher sie lieber den den offen-stehenden Mund zum athemen brauchen / als daß sie etwan so viel Müh sollten auf sich nehmen / die Nasenlöcher zu putzen. Etliche halten es für gesund / und sagen / daß also die Dünste besser weggehen / nicht so ins Haupt steigen / auch der Athem sich besser reinige / damit er nicht übel rieche / und stinkend werde. Andere das Widerspiel / und geben vor/ daß gleichwie das Schlafen auf dem Rücken schädlich schädlich / davon in der vorgehenden Frag ist gehandelt worden / also sey auch mit offenem Mund zu schlafen schädlich weil die Lunge hohl und löchericht ist / so wird sie durch die Luftröhr die unreine trübe Nacht-Lufft viel hefftiger an sich ziehen / davon eine heischere Stimme käme. es erfahren auch solche Schläfer / daß ihnen gegen den Morgen der Hals trucken und der Mund bitter ist / dahero sie öfters einen Durst bekommen; dieses aber begegnet denen / so mit zugethanem Munde schlafen / nicht / denn die äusserliche Luft kann nicht so häuffig in die Lungen kommen / sondern muß fein langsam durch die Nasenlöcher als einen Umbschweiff ein- und ausgehen / reiner in die Lungen kommen / und die Hitz des Herztens besser mäßigen. Dieses setzet auch hinzu der tieffsinnige Lemnius an einem Ort / daß durch das schlafen mit zugethanem Munde die natürliche Wärme desto besser beysammen behalten werde / durch welche nochmals die Dauung desto besser verrichtet wird.

\section{Question XV. Whether sleeping with one's mouth open is harmful?}

Mostly, it is strong eaters and drinkers who sleep with their mouths open, although there are also those who must sleep with their mouths open simply out of necessity, because their nostrils are too narrow to breathe sufficiently through the nose. Still others do it out of laziness, because they do not like to clear their noses from the snot they contain. Therefore, they prefer to use their open mouths for breathing rather than taking the pains to clean their nostrils. Some even think this [sleeping with their mouth open] to be healthy and say that this way the gases in our bodies can be released more easily, do not get to people's heads so easily, and that their breath is refreshed, so that it does not smell and get stinky. Others claim the opposite and specify that, since sleeping in a supine position is harmful, which was discussed-treated in the aforegoing question, sleeping with one's mouth open is harmful, too. This is because first as the lungs are hollow and porous, they will much more intensely suck in the impure dirty air of the night via the windpipe, which would cause a hoarse voice. Secondly such sleepers experience a dry throat and a bitter mouth around daybreak, which is why they often feel thirsty; This does, however, not happen to those who sleep with their mouths shut. For, the external air cannot get into the lungs so freely, as it must take a digression through the nostrils so that it can get into 
and out of the lungs only very slowly, thus better moderating the heat of the heart. At another place, the deep thinking scholar Lemnius adds that by sleeping with one's mouth shut, the natural warmth of the body can be retained much better, which contributes to an even better digestion.

\section{Die XVI. Frag. Woher kömmts / daß etliche unter den Schlafenden schnarchen?}

Das Schnarchen ist eine verdrießliche / beschwerliche und unannehmliche Nacht-Music / denen Beyliegenden anzuhören / und ist nichts anders / als die hinterhaltene Lufft in der Nasen /weil sie nicht frey und ungehindert durch die Nasen kommen kan / dahero diejenigen / welche voller Dünste stecken / und nicht allmählig ausdämpffen können / dergleichen die von Natur ein dickes Blut haben / oder sich berauscht schlafen legen / wie auch die / so des ungestalten Rückenliegens gewohnet / offters schnarchen müssen.

\section{Question XVI. How is it that quite a few persons snore in their sleep?}

Snoring is an irritating, arduous and unpleasant night music for those who sleep close by.

It is nothing more or less than the air trapped in the nose, because it cannot pass through the nose freely and unhindered. That is why those frequently snore who suffer from intestinal winds and cannot release flatulence by degrees, or those who by nature have thick blood or go to sleep intoxicated, as well as those who are used to keeping a supine position when sleeping.

\section{References}

1 Dickens C. The Posthumous Papers of the Pickwick Club. London, Simon and Schuster, 1949 (first published 1837).

2 Kryger MH. Sleep apnea. From the needles of Dionysius to continuous positive airway pressure. Arch Intern Med 1983: 143: 2301-2303

3 Lavie P. Who was the first to use the term Pickwickian in connection with sleepy patients? History of sleep apnoea syndrome. Sleep Med Rev 2008: 12: 5-17.

4 Grau G. Hypnologia. Dresden, Kleantes Verlag, 2013 (first published 1688).

5 Lemnius L. Levini Lemnii Medici Zirizaei Occulta Naturae Miracula, ac varia rerum documenta, probabili ratione atque artifici coniectura explicata: Quibus praeter priores fusißime recognitos ac locupletatos, accesserunt Libri duo novi ... . Simon Antverpiae, 1564. 